Faculdade

de Ciências Econômicas UFRGS
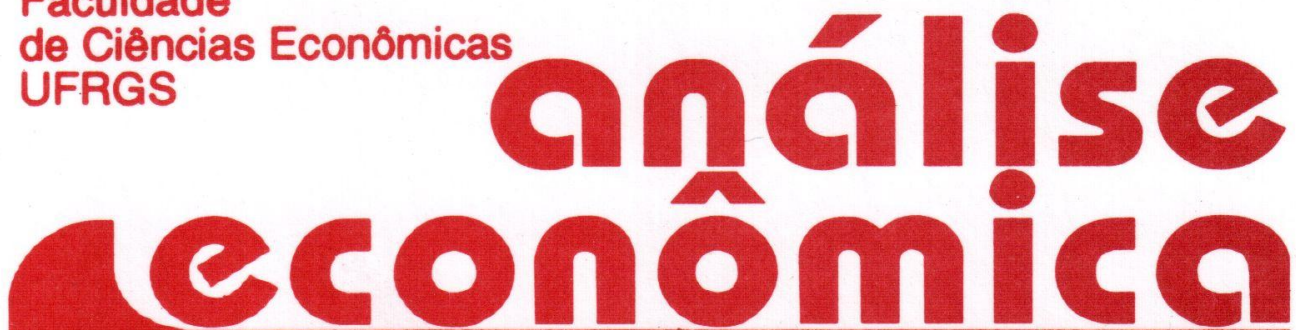

- SIDERURGIA E O PARADIGMA TECNOLÓGICO

Angela Maria Morandi

- ESTIMATING PRIVATE DEMANDS FOR PUBLIC GOODS

Eduardo Pontual Ribeiro

- KEYNES E A ATUALIDADE DA TEORIA KEYNESIANA

Fernando Ferrari Filho

- IMPRODUTIVIDADE DE UM CONCEITO DE PRODUÇÃO Raul Cristóvão dos Santos

- A NEGAÇÃo dA INEFICÁCIA DA POLÍTICA MONETÁRIA João Sicsú

- DESREgulamentAÇÃo, globa LIZAÇÃo E A CADEIA DO TRIGO Lena Lavinas

Manoel Magina

- ALUGUÉIS RESIDENCIAIS EM PORTO ALEGRE

Marco Aurélio Stumpf González

- POLICY INTERVENTION AND THE TRADE-OFF BETWEEN GROWTH AND DISTRIBUTION OF INCOME Joanílio Rodolpho Teixeira Jorge Thompson Araujo

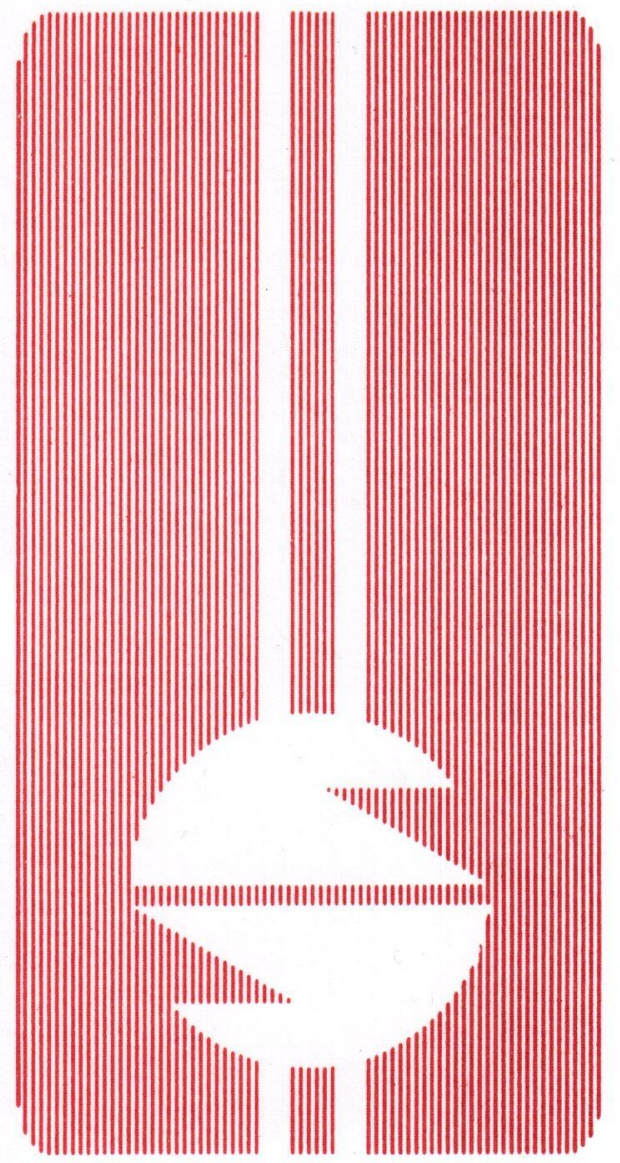


UNIVERSIDADE FEDERAL DO RIO GRANDE DO SUL

Reitora: Prof ${ }^{a}$. Wrana Maria Panizzi

FACULDADE DE CIENNCIAS ECONÓMICAS

Diretora: Prof ${ }^{\mathrm{a}}$. Otilia Beatriz Kroeff Carrion

CENTRO DE ESTUDOS E PEQUISAS ECONÔMICAS

Diretor. Prof. Fernando Ferrari Filho

DEPARTAMENTO DE CIÊNCIAS ECONÓMICAS

Chefe: Prof. Gentil Corazza

CURSO DE PÓS-GRADUAÇÃO EM ECONOMIA

Coordenador. Prof. Marcelo Savino Portugal

CURSO DE PÓS-GRADUAÇÃO EM ECONOMIA RURAL

Coordenador: Prof. Carlos Guilherme A. Mielitz Netto

CONSELHO EDITORIAL: Achyles B. Costa, Aray M. Feldens, Carlos A. Crusius, Carlos G. A. Mielitz Netto, Eduardo A. Maldonado Filho, Eduardo P. Ribeiro, Eugênio Lagemann, Fernando Ferrari Filho, Gentil Corazza, Marcelo S. Portugal, Nali J. Souza, Otília B. K. Carrion, Paulo A. Spohr, Paulo D. Waquil, Pedro C. D. Fonseca, Roberto C. Moraes, Ronald Otto Hillbrecht, Stefano Florissi, Eleutério F. S. Prado (USP), Fernando H. Barbosa (FGV/RJ), Gustavo Franco (PUC/RJ), João R. Sanson (UFSC), Joaquim P. Andrade (UnB), Juan H. Moldau (USP), Paul Davidson (Univ. of Tennessee), Werner Baer (Univ. of Illinois).

COMISSÃO EDITORIAL: Eduardo Augusto Maldonado Filho, Fernando Ferrari Filho, Gentil Corazza, Paulo Dabdab Waquil, Marcelo Savino Portugal, Roberto Camps Moraes.

EDITOR: Nali de Jesus de Souza

SECRETARIA: Cláudia Porto Silveira, Sandra Mascarello e Fábio Régis Sparremberger. Revisão de textos: Vanete Ricacheski.

FUNDADOR: Prof. Antônio Carlos Santos Rosa

Os materiais publicados na revista Análise Económica são da exclusiva responsabilidade dos autores. É permitida a reprodução total ou parcial dos trabalhos, desde que seja citada a fonte. Aceita-se permuta com revistas congêneres. Aceitam-se, também, livros para divulgação, elaboração de resenhas e recensões. Toda correspondência, material para publicação (vide normas na terceira capa), assinaturas e permutas devem ser dirigidos ao seguinte destinatário:

PROF. NALI DE JESUS DE SOUZA

Revista Análise Econômica - Av. João Pessoa, 52

CEP 90040-000 PORTO ALEGRE - RS, BRASIL

Telefones: (051) 316-3348 e 316-3440 - Fax: (051) 316-3990

nali@vortex.ufrgs.br 


\title{
A SIDERURGIA E SUA ADAPTAÇÃO AO NOVO PARADIGMA TECNOLÓGICO*
}

\author{
Angela Maria Morandi **
}

\begin{abstract}
SINOPSE
Discute-se aqui a reestruturação da indústria siderúrgica, em nível mundial, que se processou a partir de meados dos anos de 1970, em decorrência da crise energética e da conseqüente redução da intensidade do uso de aço nos principais produtos que o utilizam como insumo. Mostra-se que houve uma adaptação dessa indústria às mudanças ocorridas nos seus setores demandantes, através da introdução de inovaçóes de processos com vistas às reduçóes de custos e, especialmente, inovações em produtos, que tornaram o aço mais leve, mais maleável e mais resistente, adquirindo caracteristicas de um novo material e reconquistando seu papel de importante insumo para a indústria.
\end{abstract}

Cód. AEA: 610

Palavras-chave: Siderurgia mundial; inovações tecnológicas;

reestruturação industrial.

\begin{abstract}
Since the middle of the 1970 s, the World steel industry has restructured itself as a result of the energy crisis and consequent reduction of steel use in the main steel-intensive products. This article shows that the steel industry has adjusted its production structure in response to changes in the demand. Cost-saving innovations and, especially, product innovations have boen introduced, making steel a lighter, more malleable and more resistant product than it was before, acquiring characteristics of a new material and resume its important role in the industry as a whole.
\end{abstract}

AEA Code: 610

Key Words: Word steel industry; technological innovation; industrial restructuring

* Esse artigo resultou do Cap.1 da tese de doutorado da autora Reestruturação industrial e siderurgia. Uma análise do setor sidérúrgico brasileiro: O caso da CST, UNICAMP, 1996.

** Professora adjunta do Dep. de Economia da Universidade Federal do Espírito Santo
ANÁLISE ECONÔMICA
ANO 15
N. 28
Setem bro/97
p. 5 - 34 


\section{INTRODUÇÃO}

O objetivo deste artigo é discutir o comportamento da indústria siderúrgica, fornecedora de um dos principais produtos intermediários característicos da Segunda Revolução Industrial, frente à reestruturação produtiva e tecnológica que se processa no capitalismo a partir dos anos de 1970. O novo ambiente competitivo exigiu não só a modernização dos seus processos produtivos como também sua remodelação para poder ofertar novos produtos. Nesse processo de adaptação, a siderurgia tornou-se uma das fornecedoras dos novos materiais requeridos pelas indústrias constitutivas da Terceira Revolução Industrial.

O desenvolvimento da indústria siderúrgica se confunde com o próprio desenvolvimento e expansão do capitalismo em nivel mundial, especialmente a partir do final do século passado, quando passou a exercer um papel preponderante na constituição e consolidação das economias industrializadas. Sua importância pode ser verificada pela decisiva participação na produção dos principais meios de produção utilizados e em inúmeros produtos de consumo final - automóveis, eletrodomésticos, cutelaria, instalações e aparelhos hospitalares, dentre outros. $O$ aço está presente em muitos setores da atividade econômica, tanto que alguns indicadores da indústria siderúrgica, tais como o consumo per capita de aço ou a intensidade do consumo em relação ao produto interno são utilizados para indicar o nível de desenvolvimento industrial de um país.

$\dot{E}$ interessante notar que, pelo menos até a década de 1970, o desenvolvimento da indústria siderúrgica foi muito suscetível às variações cíclicas da economia, pois, sendo um insumo básico de setores como a indústria de transformação e da construção civil, o consumo de aço depende do comportamento do investimento e do desempenho dos demais setores da atividade econômica. No entanto, essa simbiose já não se manifesta com a mesma intensidade no período pós-1973, uma vez que o crescimento econômico verificado na economia mundial não mais se traduziu em um correspondente aumento da demanda de aço, gerando uma crise no setor muito mais prolongada e mais profunda do que a verificada para as economias em geral. O rompimento desse mutualismo (entre a siderurgia e os demais setores da atividade econômica) provocou uma reestruturação produtiva, empresarial, tecnológica e nas estratégias competitivas do setor que o colocou, de novo, em consonância com as novas bases de expansão do capitalismo, especialmente no que se refere à oferta de novos produtos e à flexibilização dos processos produtivos.

As inovações tecnológicas procuraram buscar, além de contínuas melhorias na qualidade do produto e o aumento da eficiência produtiva, respostas para as necessidades específicas da indústria em cada fase do 
seu desenvolvimento. Assim, durante as décadas de 1950 e 1960, quando a indústria siderúrgica deṕarou-se com um intenso processo de crescimento da demanda, centrado, principalmente, nos paises desenvolvidos, as inovações tecnológicas foram especialmente concentradas no sentido de possibilitar o aumento das escalas de produção dos altos-fornos e de melhorar o tratamento das matérias-primas básicas para viabilizar o seu uso mais intenso.

O período entre o início dos anos de 1970 e meados dos anos de 1980 foi marcado pela crise energética e pela sobre-capacidade do setor decorrente de uma forte retração da demanda. Além disso, ocorreu um processo de desconcentração geográfica da produção mundial, com a entrada de novos países produtores de aço. A conjugação desses fatores provocou uma intensa reestruturação produtiva, com a desativação de parte da capacidade produtiva das grandes usinas e o concomitante surgimento das miniusinas, cuja tônica é a produção de aço a partir de sucatas, com grande economia de energia. As inovações tecnológicas, nesse periodo, priorizaram a redução do consumo de produtos energéticos e de outros itens do custo de produção, bem como uma maior variedade na oferta dos produtos siderúrgicos através da diferenciação.

A partir de meados dos anos de 1980, a indústria siderúrgica, diante da estabilidade dos níveis da demanda mundial e da consolidação da reestruturação do setor, partiu para um novo tipo de inserção na estrutura produtiva, adotando formas de flexibilização dos processos produtivos. As tendências gerais das novas bases de expansão do capitalismo estão impondo profundos desafios tecnológicos ao setor, no sentido de compactar as etapas produtivas e tornar a indústria mais flexível para atender a uma demanda caracterizada por pequenos lotes de produtos diferenciados, com exigências cada vez maiores pela qualidade.

O artigo contém, além desta Introdução, mais quatro seções. A segunda faz uma breve caracterização do setor, destacando seus principais processos e produtos; a terceira trata do desempenho dessa indústria, especialmente no período pós-ll Guerra; na quarta são discutidos os principais aspectos da reestruturação produtiva e tecnológica da siderurgia, a partir da década de 1970; finalmente, a quinta seção destaca as principais conclusões.

\section{UMA BREVE CARACTERIZAÇÃO DA INDÚSTRIA SIDERÚRGICA}

Embora o aço seja um produto conhecido desde a Antigüidade, sua produção sistemática e seu amplo uso industrial iniciaram-se somente no final do Século XIX. Considerado um produto-chave da Segunda Revolução Industrial, o aço abriu novas possibilidades para os processos produtivos, 
permitindo criar e consolidar novos produtos e novos mercados e contribuindo para aumentar a produtividade do trabalho através do aperfeiçoamento dos maquinários. Tornou possivel, ainda, a produção em larga escala em muitos setores industriais, com a conseqüente concentração industrial, além de encurtar as distâncias entre os espaços geográficos e, por extensão, dos mercados, por meio de melhorias nas modalidades de transporte, sobretudo ferroviário e naval. "A indústria moderna se constituiu (e, a rigor, continua a ser construída, mesmo após o desenvolvimento dos plásticos e do concreto) sobre uma estrutura de metal, particularmente o metal ferroso" (Landes, 1969, p. 258).

O metal ferroso reúne algumas características que o tornam único frente a outros materiais e de dificil substituição em muitos tipos de uso. Suas vantagens mais destacadas são a elasticidade, a plasticidade e a dureza. $O$ aço, por sua vez, é um tipo superior de ferro e potencializa as suas vantagens. A diferença se encontra no teor de carbono; enquanto o ferro-gusa apresenta uma variação entre 2,5 a $4,0 \%$ de carbono, 0 aço varia de 0,1 a $2,0 \%$. Quanto mais elevado o teor carbônico, mais duro e menos maleável é o metal, e quanto menor aquele teor, mais ele é macio, maleável e dúctil.

O uso restrito do aço - ao contrário do ferro - à época da industrialização inglesa, se deu em função das técnicas ainda rudimentares utilizadas para a sua produção. Além de apresentar um alto grau de heterogeneidade em sua composição, sua produção era possivel apenas em pequena escala e seu preço era muito superior ao do ferro, o que inviabilizava a sua substituição.

$\mathrm{Na}$ verdade, [o aço] era um metal vendido e usado, em quantidades minimas, na fabricação de pequenos objetos de alto valor em relação ao peso, especialmente navalhas de barbear, instrumentos cirúrgicos, lâminas, tesouras, lixas e limas grossas [...]. A única área em que havia pouca ou nenhuma parcimônia era a fabricação de armas: o homem raramente usa subterfúgios no que tange ao custo dos instrumentos da morte (Landes, 1969, p. 261).

A propósito, a primeira grande inovação no processo siderúrgico adveio de uma necessidade militar, quando um projetista de armas (Henry Bessemer), em meados do século passado, concebeu um canhão longo e forte, para fabricar e vender às forças militares. Seu problema consistia em encontrar aço em lingotes maiores, com uma constituição homogênea e suficientemente barato para viabilizar seu projeto. Assim, ele próprio criou uma técnica relativamente simples e que, ainda hoje, atua como um dos princípios da produção do aço. Essa técnica consistia em soprar ar dentro e através do metal fundido, usando o calor emitido pela própria oxidação para manter o ferro liquefeito, em vez de refinar o ferro-gusa pela aplicação 
tradicional de calor na sua periferia (Landes, 1969, p. 263). A partir de então, os aperfeiçoamentos tecnológicos foram contínuos, na busca da obtenção de um produto mais homogêneo e em barras cada vez maiores, do aumento da escala de produção, da redução do tempo da corrida do aço (da descarbonização do ferro), da economia do combustível e, principalmente, para encontrar novos usos para o produto.

As inovações iniciais reduziram de 80 a $90 \%$ o custo de produção do aço bruto, entre 1860 e 1890 (Landes, 1969, p. 267). Como o ferro e o aço são mais substitutos que complementares, diante da proximidade dos seus preços e da supremacia do aço em termos de qualidade, a substituição foi inevitável - inaugurando a era do aço - tornando-o um dos produtos vitais para uma economia industrializada (Maciel, 1988, p. 3). A difusão do uso do aço provocou profundas mudanças nos meios de produção e na infraestrutura. As máquinas tornaram-se maiores, mais precisas, mais rápidas e com maior durabilidade e, como conseqüência, tornou possível a ampliação das escalas de produção, o aumento da produtividade e a produção em massa dos bens de consumo, além da fácil reposição devido à padronização das peças. O padrão tecnológico da Segunda Revolução Industrial, derivado de um elenco articulado de inovações tecnológicas aço-eletricidade-petróleo-motor a combustão -, estabeleceu as bases do desenvolvimento das economias industrializadas (Coutinho, 1982, p. 39).

Atualmente, existe uma multiplicidade de produtos ofertados pela indústria siderúrgica, diferenciados pelos formatos e pela composição do aço. Além dos produtos semi-acabados (planos e não-planos), podem-se identificar três grandes segmentos: os laminados planos comuns, os laminados não-planos comuns e os laminados especiais (planos e nãoplanos). Enquanto os dois primeiros se assemelham quanto à composição dos elementos do aço e diferem quanto aos formatos dos produtos, o último pode assumir quaisquer das formas e é altamente diferenciado pela composição química, pois é derivado do acréscimo de ligas (niquel, cromo, tungstênio, nióbio, titânio, manganês) para tornar o produto mais resistente aos agentes corrosivos e oxidantes e acentuar as propriedades de resistência à tensão, de maleabilidade e de elasticidade.

Os laminados planos comuns são constituidos pelas chapas grossas, destinadas às indústrias pesadas; bobinas e chapas finas a quente, utilizadas principalmente pela indústria automobilística; bobinas e chapas finas a frio, consumidas na indústria automobilística, na fabricação de eletrodomésticos e na de móveis de aço; chapas revestidas com camadas protetoras de zinco ou galvanizadas - mais resistentes à corrosão - e outros revestimentos (cromo, chumbo), destinadas principalmente a aplicações na indústria automobilística, de implementos agrícolas e de utilidades domésticas; folhas de flandres, com uma camada protetora de estanho, 
utilizadas principalmente na fabricação de embalagens.

Os aços laminados não-planos comuns se caracterizam pelo acentuado predomínio da dimensão comprimento sobre as demais dimensões e se apresentam em uma vasta variedade de produtos, como: trilhos e acessórios para o setor ferroviário; vergalhões para a construção civil; fio-máquina para a fabricação de arames, pregos, parafusos e similares; tubos sem costura, com larga utilização nos setores petrolifero, aeronáutica e naval; perfis leves, médios e pesados, para a construção civil, serralheria, fabricação de elevadores, mecânica pesada, setores de autopeças, implementos agrícolas e linhas de transmissão; barras de aço comum, destinadas aos setores de construção civil, serralheria e mecânico.

Os laminados em aço especial são produtos que assumem os mesmos formatos dos aços comuns, mas se diferenciam pela qualidade superior e pelo maior valor adicionado, em função da adição de elementos mais nobres na sua composição ou do maior rigor no processo de fabricação. Os principais produtos são as chapas silicosas, utilizadas largamente pelo setor elétrico; chapas de aço inoxidável, com adições de cromo e níquel, empregadas no setores mecânico e cutelaria; chapas altocarbono e ligadas, usadas para a fabricação de implementos agrícolas, bens de capital e utilidades domésticas; barras de aço especial, produtos intermediários para a construção mecânica, utilidades domésticas e autopeças; tubos sem costura, demandados pelos setores petroquímico e construção civil.

A concepção do processo de produção do aço é relativamente simples: consiste na redução do minério-de-ferro - encontrado na natureza numa associação do ferro com oxigênio, carbono, hidrogênio, enxofre e silício - a ferro-gusa, através da retirada do oxigênio, utilizando-se de processos químicos que combinam o minério com carbono. Feito isso, passa-se ao refino do ferro-gusa até que se encontre o aço desejado, através da eliminação dos resíduos e da redução do teor de carbono. A partir daí, o produto percorre a etapa final da produção, onde recebe os tratamentos necessários à sua conformação, adequada aos diversos usos a que se destina.

Essa relativa simplicidade, no entanto, é apenas aparente. A indústria siderúrgica evoluiu no sentido da ampliação da capacidade produtiva de cada planta $e$, em conseqüência, passou a movimentar uma enorme quantidade de matérias-primas, elevou sobremaneira o consumo de energéticos e seus equipamentos foram se tornando cada vez mais complexos e aperfeiçoados, na busca de crescente produtividade. Ressaltese que os principais indicadores da produtividade nessa indústria não são propriamente aqueles que medem o rendimento da mão-de-obra, mas o rendimento das matérias-primas, como o carvão e o minério-de-ferro, o 
consumo de energia por tonelada de produto e o tempo de corrida do aço, entre outros.

A evolução do processo produtivo nessa indústria, ao mesmo tempo que gerou economias de escala, resultou, também, ern crescentes entraves à sua modernização, devido ao volume e à durabilidade do capital fixo envolvido na produção e as conseqüentes dificuldades para a sua reposição e modernização. Desse modo, encontra-se no setor uma variedade de processos tecnológicos, cuja convivência pode ser explicada, em parte, pelos elevados custos de reposição dos equipamentos e pelas fortes barreiras à saida, o que torna 0 processo de modernização relativamente lento na indústria.

Normalmente, a produção siderúrgica se processa em quatro etapas bem demarcadas e por unidades industriais separadas, embora interligadas. A primeira prepara as principais matérias-primas - minério-de-ferro e carvão; a segunda, através do processo de redução, transforma o minériode-ferro em ferro-gusa; a terceira é a etapa do refino, que consiste na transformação do ferro-gusa em aço; e a quarta etapa cuida do acabamento dos produtos siderúrgicos, dando-lhes a conformação final para os diferentes usos.

Os insumos básicos para a fabricação do aço são: minério-de-ferro, carvão, sucata, ferro-ligas, fundentes (calcário), além de óleo combustível, gás natural, oxigênio, refratários, água e energia elétrica. O minério é o elemento central do processo de preparação, pois através de sucessivos beneficiamentos - retirada de impurezas e redução do teor de carbono será convertido em aço. Esses beneficiamentos são realizados por meio de aquecimento, cuja fonte energética pode ser o carvão mineral, o carvão vegetal ou a energia elétrica. Na primeira etapa, as usinas integradas utilizam as duas primeiras fontes, prevalecendo o carvão mineral, "pela razão técnica fundamental de suportar as grandes pressðes de cargas nos altos-fornos de grande escala" (Maciel, 1988, p. 8). Nas miniusinas, onde predomina o uso da redução por energia elétrica, essa etapa não é necessária. Para aumentar o rendimento das duas principais matériasprimas, as usinas integradas contam com duas unidades industriais: a sinterização, que consiste na aglomeração dos finos de minério, e a coqueria, onde o carvão mineral é queimado a fim de eliminar o gás e o alcatrão.

A unidade básica na segunda etapa é o alto-forno, onde o minério-deferro, já convertido em sínter, se transforma em ferro-gusa, através da remoção do oxigênio pelo carbono contido no carvão. $O$ coque serve tanto de combustivel como de agente redutor e os fundentes ajudam a separar as impurezas do minério. O ferro é fundido em altas temperaturas, formandose uma escória (subprodutos) sobre ele. Esta escória é eliminada, restando 
o ferro-gusa como o produto da redução. O alto-forno está entre os maiores investimentos de uma usina e é a razão principal da grande escala de produção. A etapa da redução se diferencia pelo tipo de redutor utilizado, podendo-se classificá-la em três grandes grupos: altos-fornos a coque, altos-fornos a carvão vegetal e fornos elétricos de redução.

O princípio do processo de fabricação do aço, a terceira etapa nas usinas integradas, está na oxidação de impurezas contidas no ferro-gusa. A unidade responsável nesta etapa é a aciaria, classificada conforme o processo tecnológico (equipamentos) e as matérias-primas. Os principais processos utilizados são o de forno aberto (Siemens-Martin), a aciaria elétrica e a aciaria de vasos conversores, sendo que os dois últimos se constituem nos tipos mais modernos, embora existam, ainda, usinas operando com o primeiro processo, que foi utilizado amplamente até a Segunda Guerra Mundial.

A aciaria de vasos conversores, também conhecida como BOF (Basic Oxygen Furnace) ou L. D. (as iniciais de duas siderúrgicas austriacas, onde foi usado pela primeira vez esse processo), consiste em se carregar sucata, ferro-gusa líquido e fundentes para grandes conversores inclinados nos quais, depois de serem colocados em posição vertical, é injetado oxigênio puro por meio de lanças resfriadas a água. O oxigênio eleva a temperatura provocando reações que queimam as impurezas do ferro-gusa líquido, convertendo-o em aço. Além da elevada capacidade de produção, a vantagem desse processo é a redução do ciclo de produção ou da corrida do aço - tempo que vai de uma carga a outra. Enquanto no processo Siemens-Martin a corrida dura de 8 a 11 horas, no L. D. a mesma se reduz a cerca de $\mathbf{4 5}$ minutos.

A aciaria elétrica, ou o forno a arco elétrico, opera basicamente com sucata e sua escala de produção é bem menor do que no processo anterior, configurando as chamadas miniusinas, cuja principal vantagem consiste em produzir quantidades menores de certas linhas de aços especiais para atender a demandas especificas. $O$ processo consiste em carregar-se 0 forno com sucata que é fechado com uma tampa em forma de abóbada na qual são introduzidos grandes eletrodos cilíndricos de carbono ou grafita, que levam a corrente à carga do forno. A eletricidade é usada unicamente para 0 aquecimento, o qual se origina da proximidade do arco elétrico e da resistência elétrica do próprio banho de aço. É nessa etapa do refino que, eventualmente, adicionam-se elementos de liga para a obtenção de aços especiais, para alcançar algumas propriedades requeridas pelos diferentes usos do produto; como, por exemplo, manganês, para criar resistência ao desgaste; cobre, para evitar a corrosão; cromo e níquel, para inoxidá-lo.

A última etapa consiste em moldar o aço para os diversos usos conforme relacionado anteriormente nas descrições dos produtos. 
Primeiramente, o aço líquido é transformado em lingotes endurecidos, através de dois processos alternativos: o lingotamento convencional, em que $o$ aço é despejado em lingoteiras de várias formas e tamanhos e, após o esfriamento, transportado para fornos-poços onde é reaquecido a uma temperatura uniforme, passando pelo laminador-desbastador e transformado em placas - produtos semi-acabados que irão alimentar a laminação. O outro processo é o lingotamento contínuo, ou seja, o aço líquido é despejado diretamente nos moldes e guilhotinado em tamanhos específicos. Com esse método ocorre uma substancial redução do consumo de energia, resultando em melhor rendimento e qualidade do produto, além de dispensar equipamentos como fornos-poços, lingoteiras e laminadordesbastador, procedimentos comuns no processo convencional. Em seguida, os lingotes são levados para a laminação, onde o aço, finalmente, assume a forma na qual será utilizado pelos consumidores finais. A laminação inclui uma grande variedade de equipamentos apropriados à conformação do produto, além de tarefas específicas necessárias para melhorar a qualidade do aço.

\section{DESEMPENHO DA SIDERURGIA MUNDIAL}

Até o início dos anos de 1970, a produção siderúrgica mundial esteve fortemente atrelada e sensivel às variações ciclicas da economia, conforme mostra a Tabela 1. Até a década de 1940, ocorrem rápidas e profundas oscilações, gerando uma permanente instabilidade no setor. Após esse período, a siderurgia mundial passou por uma fase única em sua história foram vinte e cinco anos de crescimento contínuo e a taxas muito elevadas, refletindo o desempenho dos demais setores da atividade econômica. A produção média do periodo 1950/54 superou a do qüinqüênio anterior em $58,6 \%$ e continuou em ritmo acelerado até a primeira metade dos anos de 1970. A produção cresceu de 189,8 Mt (milhões de toneladas), em 1950, para $703,5 \mathrm{Mt}$, em 1974. A partir de então, inaugurou-se uma nova fase com características bem distintas das verificadas nos ciclos anteriores: nem oscilações rápidas e profundas, nem elevadas taxas de crescimento. A indústria siderúrgica, depois de 1974, manteve um nivel de produção mais ou menos estável, a não ser no período 1985/89, quando ocorreu uma ligeira recuperação $(8,5 \%$ em relação ao qüinqüênio anterior), mas que não se confirmou como um novo patamar de produção.

No período posterior à Segunda Guerra podem-se identificar duas fases distintas. A primeira, entre 1950 e 1974, foi marcada por elevadas taxas de crescimento com mudanças contínuas do patamar de produção. Esse vigoroso crescimento foi induzido, de um lado, pela reconstrução da capacidade produtiva e da infra-estrutura econômica dos países europeus e 
do Japão e, por outro, pela demanda crescente dos setores-líderes do crescimento industrial desse período (metal-mecânica, automobilística e bens de consumo durável). A segunda fase, a partir de 1974, se caracterizou pela estabilidade da produção siderúrgica mundial, apresentando pequenas oscilações anuais. Outras características importantes ajudam a distinguir essas duas fases. Além das mudanças relacionadas com o comportamento da demanda, o setor passou por uma profunda reestruturação sob múltiplos aspectos: modificações nos fluxos e na intensidade do comércio internacional, alterações na distribuição geográfica da produção mundial, inovações tecnológicas em processos e em produtos, bem como mudanças na condução das políticas econômicas para o setor.

Tabela 1. Produção mundial de aço bruto, 1900/1904 e 1990/1993

\begin{tabular}{c|c|c}
\hline Qüinqüênios & Produçäo média $\left(10^{6} t\right)$ & Crescimento $(\%)$ \\
\hline $1900 / 1904$ & 33,24 & - \\
$1905 / 1909$ & 48,94 & $+47,2$ \\
$1910 / 1914$ & 66,08 & $+35,0$ \\
$1915 / 1919$ & 72,50 & $+9,7$ \\
$1920 / 1924$ & 68,66 & $-5,3$ \\
$1925 / 1929$ & 103,28 & $+50,4$ \\
$1930 / 1934$ & 73,16 & $-29,2$ \\
$1935 / 1939$ & 121,32 & $+65,8$ \\
$1940 / 1944$ & 151,32 & $+24,7$ \\
$1945 / 1949$ & 135,20 & $-10,7$ \\
$1950 / 1954$ & 214,48 & $+58,6$ \\
$1955 / 1959$ & 285,14 & $+32,9$ \\
$1960 / 1964$ & 370,18 & $+29,8$ \\
$1965 / 1969$ & 501,40 & $+35,4$ \\
$1970 / 1974$ & 641,60 & $+28,0$ \\
$1975 / 1979$ & 691,42 & $+1,1$ \\
$1980 / 1984$ & 688,36 & $-0,4$ \\
$1985 / 1989$ & 747,00 & $+8,5$ \\
$1990 / 1993$ & 738,45 & $-1,1$ \\
\hline
\end{tabular}

Fonte. IISI (International Institute of Steel and Iron)

Observando-se os dados da Tabela 2, percebe-se as alterações na distribuição geográfica da produção mundial de aço. Essas mudanças vêm se processando desde os anos de 1950 e foram acentuadas a partir da década de 1970. Como a produção mundial de aço bruto esteve praticamente estagnada a partir de então, as alterações percentuais na produção de cada pais ou grupo de países tornam-se mais significativas, pois a redução nesse percentual expressa uma diminuição absoluta da tonelagem produzida. $\mathrm{E}$ foi o que realmente ocorreu com a siderurgia 
americana e, em menor intensidade, com a dos países da Comunidade Econômica Européia (CEE).

Em 1950, os Estados Unidos exerciam a liderança da siderurgia mundial, produzindo $48 \%$ do total do aço mundial. Em 1955, quando a fase de reconstrução européia e japonesa foi praticamente completada, a siderurgia americana produzia o equivalente a $40 \%$ do aço bruto mundial. Nos vinte anos seguintes, apesar do fenomenal crescimento da oferta mundial de aço bruto, a siderurgia americana não mais conseguiu reproduzir sua performance mantida até meados dos anos de 1950 . Em 1970 , sua participação já havia caído para $20 \%$ e, em 1990 , para apenas $11,6 \%$. Esse decréscimo percentual resultou na queda da tonelagem produzida, principalmente a partir de 1973. Em uma década, a produção americana de aço teve uma redução de $44 \%$, passando de $136,8 \mathrm{Mt}$, em 1973, para 76,8 Mt, em 1983.

Um pouco menos grave foi a situação da siderurgia européia, particularmente para o grupo dos países da CEE, que constituía o segundo produtor mundial de aço em 1950, com $27,4 \%$ da produção total. Essa participação se elevou durante a década de 1960, mas depois iniciou uma queda até se estabilizar, nos anos de 1980 , em torno dos $17,5 \%$. Com isso, a tonelagem anual de aço produzido caiu de 151,2 Mt, em 1973, para 109,5 Mt, em 1983, atingindo, em 1990, o equivalente a 133,8 Mt. O Japão, ao contrário desses países, despontou como a grande potência siderúrgica a partir da década de 1960. De uma posição insignificante no ranking mundial, em 1950, quando produziu 4,8 Mt, passou a 22,2 Mt, em 1960, e aumentou em mais de quatro vezes sua produção durante a década, alcançando $93,5 \mathrm{Mt}$, em 1970, quando se consolidou como o principal país produtor de aço, atingindo, em $1990,110,1$ Mt $(14,3 \%$ da produção mundial).

Outra mudança significativa, e que provocou forte impacto no mercado internacional de aço, foi o rápido e concentrado crescimento da produção siderúrgica nos países em desenvolvimento - da América Latina e da Ásia após 1970. A produção de aço do conjunto desses paises aumentou de 26 Mt, em 1970, para $51 \mathrm{Mt}$, em 1980, atingindo $91 \mathrm{Mt}$, em 1990, correspondentes a $11,8 \%$ da produção mundial. A evolução dessa capacidade produtiva foi decorrência de uma política deliberada dos seus respectivos governos para substituir importações, sobretudo de bens intermediários. Por outro lado, de virtuais importadores, passaram a ofertantes de aço no mercado mundial, uma vez que os investimentos realizados geraram uma capacidade de produção acima da capacidade de consumo interno, acumulando vantagens competitivas com as novas plantas e/ou ampliação em usinas já existentes, pois foi possivel incorporar as tecnologias mais avançadas disponiveis no momento das decisões 
desses investimentos.

Tabela 2. Participação na produção mundial

de aco bruto em regiões e paises selecionados,1950/1993 (\%)

\begin{tabular}{l|r|r|r|r|r|r|r|r|r}
\hline \multicolumn{1}{c|}{ Países/regióes } & \multicolumn{1}{|c|}{1950} & 1960 & 1966 & 1970 & 1975 & 1980 & 1985 & 1990 & 1993 \\
\hline Japão & 2,5 & 6,4 & 10,2 & 15,7 & 15,9 & 15,6 & 14,6 & 14,3 & 13,7 \\
Estados Unidos & 47,9 & 26,5 & 25,9 & 20,0 & 16,4 & 14,2 & 11,1 & 11,6 & 12,0 \\
CEE & 27,4 & 28,1 & 24,1 & 24,2 & 21,1 & 19,5 & 18,6 & 17,4 & 17,9 \\
SUBTOTAL & 77,8 & 61,0 & 60,2 & 59,9 & 53,4 & 49,3 & 44,3 & 43,3 & 43,6 \\
BRASIL & $\ldots$ & $\ldots$ & 0,8 & 0,9 & 1,3 & 2,1 & 2,9 & 2,7 & 3,5 \\
Coréia do Sul & $\ldots$ & $\ldots$ & 0,3 & 0,4 & 0,5 & 1,2 & 1,9 & 3,0 & 4,5 \\
Taiwan & $\ldots$ & $\ldots$ & 0,1 & $\ldots$ & 0,1 & 0,5 & 0,7 & 1,3 & 1,7 \\
Países em desen- & & & & & & & & & \\
volvimento & 2,1 & $\ldots$ & 3,6 & 3,8 & 4,8 & 7,1 & 9,7 & 11,8 & 15,9 \\
União Soviética & 14,4 & 18,8 & 20,6 & 19,5 & 22,0 & 20,7 & 21,5 & 20,1 & $\ldots$ \\
China & $\ldots$ & 3,9 & 2,6 & 3,0 & 3,7 & 5,1 & 6,5 & 8,6 & 12,3 \\
TOTAL (1.000t) & 189,8 & 347,1 & 469,3 & 595,3 & 643,5 & 716,2 & 718,9 & 770,0 & 725,3 \\
\hline
\end{tabular}

Fonte: IISI; para os anos 1950/60/66, extraído de Maciel, 1988, p 258.

${ }^{1}$ Inclui: Alemanha Ocidental, Reino Unido, França, Itália, Bélgica, Espanha, Luxemburgo e Países Baixos.

${ }^{2}$ Inclui: Brasil, México, Venezuela, Argentina, Índia, Turquia, Coréia do Sul, Coréia do Norte e Formosa.

Percebe-se que o maior destaque da primeira fase do pós-ll Guerra foi a troca da posição de liderança entre a siderurgia americana e a japonesa. Depois de exercer uma liderança mundial no setor por mais de 70 anos, os produtores americanos começaram a ser ameaçados no seu próprio mercado doméstico, com niveis expressivos e crescentes das importações, que aumentaram de $3 \mathrm{Mt}$, em 1960, para $18 \mathrm{Mt}$, em 1968, provenientes, principalmente, do Japão e da CEE (Borrus, 1983, p. 69).

O desenvolvimento da siderurgia americana havia se amparado em algumas vantagens comparativas e no fortalecimento do oligopólio formado pelo segmento das grandes usinas integradas. Essas vantagens eram baseadas no significativo tamanho do mercado doméstico, na abundância de matérias-primas para a indústria, na qualificação da mão-de-obra e no desenvolvimento de outros setores da indústria americana, gerando um fluxo contínuo de demanda para a siderurgia (Borrus, 1983, p. 71). Ao mesmo tempo, os grandes produtores, que respondiam por cerca de $85 \%$ da produção siderúrgica, constituíram um cartel poderoso em vista das fortes barreiras à entrada no setor. Os menores produtores internos e as importações não se traduziam em ameaça à estabilidade do mercado, pois ocupavam uma margem insignificante da oferta interna. Assim, os preços podiam ser estabelecidos em patamares elevados, gerando uma acumulação interna considerável para as grandes firmas atuantes no cartel. 
É nesse contexto que deve ser entendido o início do declínio da siderurgia americana e a perda de sua competitividade. Durante a década de 1950, foram realizados significativos investimentos em ampliação da capacidade produtiva, nos mesmos moldes tecnológicos preexistentes. Segundo Maciel (1988, p. 115) a siderurgia americana "insistiu em alimentar com novos investimentos velhas unidades". Existiam, naquele momento, duas opções tecnológicas para a instalação dos altos-fornos: o processo Siemens-Martin e a aciaria de vasos conversores. $O$ primeiro, predominante nas maiores usinas americanas, já se encontrava em um estágio avançado da curva de aprendizado pelos participantes do processo, desde os produtores dos equipamentos, a montagem das usinas, até a mão-de-obra qualificada, a formação dos engenheiros e técnicos. Em vista disso, a continuidade de sua adoção seria mais apropriada por envolver menores riscos na construção e instalação das novas usinas e um menor tempo de investimento. O segundo processo, desenvolvido pelos japoneses, era relativamente recente e não havia sido, ainda, plenamente testado, embora prometesse uma produção com custos bem mais reduzidos do que o processo anterior, além da redução do nivel de poluentes durante a operação. Essas duas tecnologias foram avaliadas e a escolha recaiu sobre a primeira. Segundo Borrus (1983) esta opção foi fortalecida não só pela maior incerteza frente a uma inovação radical, mas também pelo receio de uma futura desestruturação na coordenação do oligopólio, uma vez que, envolvendo menores custos de produção, os preços estabelecidos teriam que ser revistos.

A estratégia de expansão da siderurgia japonesa, nos anos de 1950, foi bem diferente. Além do objetivo imediato em atender às necessidades da reconstrução da infra-estrutura e da capacidade produtiva destruídas pela guerra, a indústria siderúrgica deveria atentar para duas outras metas estabelecidas pelo governo japonês em conformidade com a classe empresarial. De uma parte, conquistar os mercados externos para gerar divisas e sustentar as importações de produtos não disponíveis no mercado interno, principalmente alguns importantes bens intermediários; de outra, contribuir para a melhoria da competitividade de outros setores industriais automobilístico, naval, máquinas-ferramentas -, garantindo o fornecimento de aço com baixo custo. Ambas as metas estabelecidas convergiam para a busca por inovações em direção à ampliação das escalas e à redução de custos.

A indústria japonesa preocupou-se, desde os primeiros anos da década de 1950 , com a introdução de inovações e a manutenção de um ritmo acelerado de progresso tecnológico em termos de equiparnentos e práticas operacionais. Para tanto, foram implementados sistemas eficientíssimos de atualização tecnológica [ . . ]; no momento de sua maior fase de expansão, ao final dos anos de 1950 e na década de 1960, as novas 
plantas já adotaram o forno de oxigênio básico, o lingotamento contínuo e a automação dos processos (Maciel, 1988, p. 110).

A competitividade alcançada pela siderurgia japonesa e a conquista de fatias crescentes dos mercados externos, incluindo o mercado americano, se explica pela busca contínua do desenvolvimento de novas tecnologias de processos, com vistas à redução dos custos de produção. Conforme salienta Szekely (1994), a principal motivação da indústria siderúrgica, nos anos de 1950 e 1960, era produzir da forma mais eficiente e em escalas cada vez mais ampliadas, já que a prioridade dos setores demandantes era o atendimento na quantidade e no preço do aço. Os gigantescos altosfornos do Japão, com escalas mínimas de três a quatro milhões de toneladas/ano, se tornaram o paradigma dessa indústria, apesar dos elevados custos de investimento e da reduzida flexibilidade dos processos.

Os anos de 1960 foram críticos para a siderurgia americana, pois o mercado interno foi sendo, crescentemente, tomado pelas importações, cujos preços se situavam em um patamar incompativel com o nível de custos das usinas domésticas. Como agravante, o setor enfrentou alguns movimentos paredistas dos trabalhadores, organizados em fortes sindicatos nacionais, na década anterior, resultando em elevações salariais bem superiores aos salários pagos nos demais setores industriais, bem como nas indústrias congêneres do Japão e da Alemanha, por exemplo (Crandall, 1981, p. 36-7).

$\mathrm{Em}$ que pese os investimentos recentes, a indústria procurou remodelar suas linhas de produção numa vã tentativa de alcançar os níveis de produtividade japoneses, porém, além dos elevados custos dessa modernização, os resultados não foram animadores, o que fez com que os grandes produtores de aço mudassem sua estratégia em direção ao protecionismo estatal. Conforme atesta Maciel (1988, p. 117):

A estrutura de preços da indústria era altamente estável, [assim] seria difícil esperar decisōes radicais no que se refere ao padräo produtivo da grande maioria das usinas, vale dizer, o sucateamento das instalações operadas via processo SiemensMartin e a adição de capacidade instalada (greenfields capacity). Quando volumes crescentes de importações começam a dar entrada nos Estados Unidos durante o primeiro quiinquênio dos anos de 1960 , os grandes produtores integrados americanos passam a trilhar o caminho de menor resistência investimentos em modernização, não em capacidade nova."

Crandall aponta três razões predominantes para explicar o declínio da posição dos Estados Unidos no mercado mundial de aço: os preços das matérias-primas, os custos de transporte maritimo e as novas tecnologias. A primeira razão deve-se à redução do diferencial dos preços do carvão metalúrgico e do minério-de-ferro entre Estados Unidos e Japão. No 
período $1956 / 68$, os preços do carvão metalúrgico vigentes nos Estados Unidos praticamente não se alteraram, situando-se em torno de US\$ 10/tonelada, enquanto que no Japão os preços sofreram uma queda de $35 \%$, passando de US\$22,1 para US $\$ 14,4$ por tonelada. A relação entre os preços praticados nos dois países caiu de 2,2 para 1,4, nesse periodo, sendo que o diferencial continuou favorável aos produtores japoneses nos anos subseqüentes, até que, em 1976, o produto se tornou mais barato no Japão do que nos Estados Unidos (Tabela 3). O caso do minério-de-ferro é ainda mais revelador da redução dos custos siderúrgicos no Japão. Os preços do produto no Japão, em 1957, eram $89 \%$ superiores aos do mercado americano e, já em 1968, menores em cerca de $10 \%$. Além disso, a tendência dos preços americanos foi de contínuo crescimento, com um aumento de $60 \%$, no periodo $1956 / 73$-, ao contrário do Japão, que experimentou uma queda de $33 \%$.

Tabela 3. Preços de minério de ferro e carvão metalúrgico nos Estados Unidos e no Japão, 1956/1976 (US\$/t líquida) ${ }^{1}$

\begin{tabular}{c|c|c|c|c}
\hline \multirow{2}{*}{ Anos } & \multicolumn{2}{|c|}{ Carvão metalúrgico } & \multicolumn{2}{c}{ Minério de ferro } \\
\cline { 2 - 5 } & EUA & Japão & EUA & Japão \\
\hline 1956 & 9,85 & 22,14 & 9,63 & 16,69 \\
1957 & 10,77 & 26,22 & 10,42 & 19,69 \\
1960 & 10,56 & 15,63 & 11,15 & 12,88 \\
1965 & 9,65 & 14,27 & 11,80 & 12,17 \\
1968 & 10,59 & 14,40 & 12,31 & 11,09 \\
1970 & 12,27 & 18,29 & 13,05 & 10,74 \\
1973 & 19,79 & 21,61 & 15,48 & 11,12 \\
1974 & 34,22 & 40,71 & 19,62 & 13,26 \\
1976 & 56,04 & 53,60 & 27,62 & 15,81 \\
\hline
\end{tabular}

Fonte: Extraído de Crandall $(1981$, p. 21)

Nota ${ }^{1}$ Inclui seguros e fretes

O declínio dos preços das matérias-primas básicas da indústria siderúrgica deve-se, em parte, ao crescimento da oferta mundial com a entrada de novos países no mercado internacional, gerando uma relativa desconcentração da oferta global, especialmente do minério-de-ferro. Os Estados Unidos eram responsáveis por $24 \%$ da oferta desse produto, no período 1954/58, e por apenas $9 \%$, em 1976. Porém, parte do declínio dos preços é explicada pela segunda razão apontada acima, ou seja, a queda nos custos do transporte maritimo por tonelada desses produtos. As dificuldades decorrentes da escassez interna das matérias-primas básicas da siderurgia (carvão e minério-de-ferro) no Japão foram superadas, principalmente, pelo desenvolvimento de navios de grande porte, reduzindo 
os custos de transporte desses produtos ao ponto de torná-los compatíveis com a siderurgia ocidental. Por exemplo, os custos do transporte de uma tonelada de minério-de-ferro do Brasil para o Japão cairam $60 \%$, entre 1957 e 1968 (Crandall, 1981, p. 22/3).

A terceira razão do declínio da siderurgia americana em relação à japonesa, e talvez a mais importante, é explicada por fatores relacionados à tecnologia das usinas integradas americanas. Com efeito, Maciel (1988, p. 270) mostra a relativa lentidão das usinas integradas americanas em adotar o alto-forno de oxigênio básico. Em 1970, o Japão produzia $79 \%$ do aço bruto com o novo processo e, tão-somente, $4 \%$ com o processo SiemensMartin, enquanto que nos Estados Unidos esses percentuais eram de 48 e $36 \%$, respectivamente. Em 1981, quando o Japão já havia abolido os velhos fornos, as siderúrgicas americanas ainda produziam $11 \%$ do aço bruto com esse processo. $O$ crescimento do uso dos fornos a arco elétrico deve-se à proliferação das miniusinas que, ao contrário das usinas integradas americanas, apresentaram um excelente desempenho, a partir dos anos de 1970. No tocante ao lingotamento contínuo, o atraso americano se repete. Em 1973, 21\% do aço japonês já era produzido através desse processo, contra $7 \%$ do americano. Em 1980, esses percentuais eram de $60 \%$ e $20 \%$, respectivamente e, em 1985 , de $91 \%$ e $44 \%$, sendo que a utilização do lingotamento contínuo é uma importante fonte de redução dos custos de produção e origem de melhorias substanciais na qualidade do aço.

A intensidade e os fluxos do comércio mundial do aço alteraram-se expressivamente no período pós-ll Guerra, especialmente a partir dos anos de 1970 , modificando a importância relativa dos grandes exportadores de aço. Em primeiro lugar, destaca-se o aumento das exportações mundiais de aço em relação ao total produzido, justamente quando ocorre um duplo processo na indústria siderúrgica: de um lado, a desconcentração da produção mundial, com o início e/ou a expansão da produção de aço em muitos outros países; de outro lado, as modificações nos volumes comercializados de aço bruto são concomitantes à estagnação da produção mundial. As exportações de produtos siderúrgicos evoluem de $10,7 \%$ da produção total, em 1950, para 30,1\%, em 1991 (Tabela 4), sendo que o volume comercializado no mercado internacional evoluiu de 20,5 Mt para $221,5 \mathrm{Mt}$, no mesmo período, o que equivale a um crescimento de $981 \%$, enquanto a produção se expandiu em $283 \%$.

Em segundo lugar, modificam-se os fluxos desse comércio: os Estados Unidos tornaram-se um país eminentemente importador, enquanto o Japão passou a dominar as exportações mundiais, crescendo sua participação de 4,8\%, no periodo 1948/52, para 25,3\%, em 1975 (CEPAL, 1984, p. 17 e 21). Os Estados Unidos apresentaram uma tendência declinante tanto na 
Tabela 4. Exportações em relação à produção mundial de aço, 1950/91(10 $t)$

\begin{tabular}{c|c|c|c}
\hline Ano & Exportações (A) & Produção (B) & A/B (\%) \\
\hline 1950 & 20,5 & 192,0 & 10,7 \\
1955 & 34,0 & 270,5 & 12,6 \\
1960 & 52,7 & 345,5 & 15,3 \\
1965 & 78,5 & 457,0 & 17,2 \\
1970 & 117,5 & 595,3 & 19,7 \\
1975 & 149,2 & 643,5 & 23,2 \\
1980 & 183,0 & 716,2 & 25,6 \\
1985 & 221,5 & 718,9 & 30,8 \\
1990 & 217,9 & 770,0 & 28,3 \\
1991 & 221,5 & 735,8 & 30,1 \\
\hline
\end{tabular}

Fonte: IISI (International Institute of Steel and Iron).

produção quanto nas exportações mundiais, enquanto o Japão teve um crescimento derivado da forte expansão do seu mercado interno, que praticamente dobrou nesse período, conjugada a uma política de proteção da indústria local contra as importações e de um agressivo aumento das exportações. Durante a década de 1980 , a economia japonesa elevou seu consumo de aço bruto em $21,5 \%$, enquanto sua produção experimentou uma ligeira redução, ou seja, parte do consumo passou a ser complementada com importações, que representaram $8,9 \%$ do consumo, em 1991, fato inédito para o país até então. Em contrapartida, houve uma redução nos índices de exportação da produção interna, passando de $26,7 \%$, em 1980 , para $16,3 \%$, em 1991 , reduzindo sua participação no mercado mundial. Enquanto o Japão foi responsável por $21,2 \%$ das exportações de aço em 1980, chegou, em 1991, com 10,5\%.

A economia americana experimentou uma forte redução na produção de aço, em 1982, equivalente a $38 \%$ (de 109,6 Mt para 67,7 Mt), continuando com os niveis baixos durante toda a década de 1980. De exportadores líquidos no mercado internacional, passaram à condição de importadores líquidos, sendo que as importações atingiram $16,2 \%$ do consumo interno, em 1991, equivalente a $8,8 \%$ das importações mundiais. Segundo estudo da CEPAL (1984, p. 18), em 1980, 36\% dessas importações eram provenientes do Japão e $24 \%$ da CEE. Nota-se que a relação importação/consumo aumentou mais de dez vezes para os Estados Unidos, no pós-ll Guerra - de $1,5 \%$, no periodo $1948 / 52$, para $16,2 \%$, em 1991 (Tabela 5). De outra parte, a relação exportação/produção tornou-se insignificante no mesmo periodo - enquanto participaram no mercado exportador com $25 \%$, no imediato pós-ll Guerra, passaram para próximo dos $3 \%$, a partir dos anos de 1970. 
Tabela 5. Relações importação/consumo e exportação/produção de regiões e países selecionados,1975-1991 (\%)

\begin{tabular}{l|r|r|r|r|r|r}
\hline \multirow{2}{*}{ Países/regiões } & \multicolumn{3}{|c|}{ importac̃o/consumo } & \multicolumn{3}{|c}{ exportação/produção } \\
\cline { 2 - 7 } & \multicolumn{1}{|c|}{1975} & 1980 & 1991 & 1975 & 1980 & 1991 \\
\hline Países industrializados & 16,2 & 19,4 & 26,7 & 24,0 & 27,3 & 32,6 \\
Japão & 0,1 & 1,4 & 8,9 & 28,3 & 26,7 & 16,3 \\
Estados Unidos & 9,5 & 12,3 & 16,2 & 2,6 & 3,7 & 7,3 \\
CEE & 28,0 & 36,2 & 49,7 & 38,5 & 45,0 & 54,8 \\
Países em desenvolvimento & 50,5 & 48,5 & 39,6 & 7,1 & 16,5 & 24,7 \\
Coréia do Sul & 60,7 & 31,7 & 31,7 & 45,0 & 52,3 & 29,6 \\
Brasil & 25,9 & 4,8 & 1,7 & 1,2 & 9,8 & 48,2 \\
Taiwan & 64,3 & 49,0 & 48,0 & 28,6 & 23,5 & 14,5 \\
Economias planificadas & 10,5 & 9,2 & 4,2 & 8,1 & 7,8 & 7,7 \\
Total Mundial & 17,5 & 19,5 & 22,4 & 17,7 & 19,6 & 23,1 \\
\hline
\end{tabular}

Fonte: IISI (International Institute of Steel and Iron)

Nos países europeus, a produção de aço ficou praticamente estagnada a partir de meados da década de 1970, apenas com ligeiras oscilações, que resultou em perda da participação na produção mundial. No entanto, foi crescente sua presença no mercado internacional de aço, atingindo niveis realmente elevados, se comparados com as demais regiões. Em geral, os países membros da CEE são exportadores líquidos e tanto as importações quanto as exportações foram ascendentes em todo o período. Em conjunto, esses países foram responsáveis por $31,7 \%$ das importações mundiais de aço, em 1980 , e por $37,8 \%$, em 1991, e no mercado exportador suas participações foram de $45,6 \%$ e $44,2 \%$, respectivamente. Ressalte-se, no entanto, que cerca de $75 \%$ desse volumoso comércio circula entre os próprios membros da CEE. A relação exportação/produção se elevou de $38,5 \%$, em 1975 , para $54,8 \%$, em 1991; enquanto que a relação importação/consumo aumentou de $28 \%$ para $49,7 \%$, no mesmo período, para o conjunto dos países da CEE.

O bloco de paises com economias planificadas é, obviamente, muito mais fechado ao comércio externo. Embora respondendo por cerca de um terço da produção mundial, não se destaca no mercado internacional, sendo que, em 1991 , suas exportações atingiram $11 \%$ do volume mundial e as importações apenas $6 \%$. Mesmo assim, mais da metade desse comércio foi realizado intrabloco. A China praticamente triplicou sua produção de aço nos últimos 25 anos - de 23,9 Mt para $71 \mathrm{Mt}$-, correspondentes a 9,6\% da produção mundial.

Uma outra alteração no mercado internacional do aço, cujos impactos não podem ser desprezados, foi a rápida ampliação da capacidade produtiva de alguns países do grupo de países em desenvolvimento, no 
período mais recente. De importantes importadores, passaram a suprir as necessidades de consumo interno e se capacitaram para ingressar no mercado exportador com significativas vantagens de custo, haja vista as instalações novas e a modernização/ampliação das antigas plantas, com efetiva incorporação de inovações nos processos produtivos. A partir de 1975, foram registradas elevadas taxas de crescimento da produção de aço nesses países, com destaque especial para a Coréia do Sul e Taiwan, cujas quantidades produzidas evoluiram de 3,2 Mt, em 1975, para 32,6 Mt, em 1993, na Coréia do Sul e de 0,6 Mt para 12,3 Mt em Taiwan, no mesmo período (conforme se depreende da Tabela 2). Como resultado, a contribuição à produção mundial dos países em desenvolvimento saltou de $4,8 \%$, em 1975, para 15,9\%, em 1993. Embora, no conjunto, ainda sejam importadores líquidos, receptores de um terço das importações mundiais, suas exportações alcançaram níveis consideráveis, evoluindo de 2,3 Mt, em 1975, para $27,5 \mathrm{Mt}$, em 1991, ou $16,2 \%$ do total das exportações mundiais, sendo que a Coréia do Sul e o Brasil são os principais responsáveis por essa performance, pois suas exportações equivalem a $67,6 \%$ das exportações totais do grupo (conforme dados do IISI). Em conseqüência, foram sendo reduzidos os niveis de dependência das importações - em 1975, 50,5\% do consumo interno era proveniente do mercado internacional; já em 1991, apesar da elevação do consumo interno, esse indice cai para $39,6 \%$. Da mesma forma, a relação exportação/produção aumenta de $7,1 \%$, em 1975 , para $24,7 \%$, em 1991, sendo que o Brasil chegou a exportar $48,2 \%$ de sua produção total nesse mesmo ano (Tabela 5).

\section{REESTRUTURAÇÃO PRODUTIVA E TECNOLÓGICA}

No início da década de 1970, já eram visiveis os sinais de estagnação após o longo período de crescimento das economias desenvolvidas, apresentando tendência de sobreinvestimento nos principais setores industriais, que conformaram o padrão de crescimento do pós-ll Guerra; evidenciando, ainda, o esgotamento da capacidade de geração de inovações tecnológicas do paradigma vigente - um padrão tecnológico que se desenvolveu na busca de economias de escala e na padronização dos produtos e que se caracterizava por um elevado nível de consumo de materiais e de energia.

A crise do capitalismo mundial, a partir de 1973, ocorreu num momento muito delicado para a siderurgia, visto que haviam sido decididos investimentos em ampliação da capacidade produtiva, nos anos imediatamente anteriores, na maioria dos países desenvolvidos. Considerando-se a extensão do tempo necessário à instalação de uma 
usina integrada, parte considerável dos investimentos decididos anteriormente ainda estava por ser concluída e a entrada em operação das usinas ocorreu durante a crise, que atingiu duramente o setor. A Tabela 6 mostra que, entre 1974 e 1976, a capacidade real instalada aumentou $7 \%$ nas economias desenvolvidas, enquanto o grau de utilização caiu $16 \%$, ou seja, da plena utilização das instalações, em 1974, chegou-se ao nivel de $84 \%$. A partir de 1978 , a capacidade instalada estabilizou-se nesses países, porém continuaram enfrentando uma crescente ociosidade, destacando-se a siderurgia americana que ocupou um nivel pouco superior à metade de sua capacidade, em 1982.

A crise afetou o setor siderúrgico não só pela retração da demanda, mas, sobretudo, pelos impactos da elevação dos preços dos insumos energéticos e dos custos financeiros. $O$ aumento da capacidade ociosa nas usinas contribuiu ainda mais para a elevação dos custos de produção, já que seus custos fixos totais são extremamente elevados, o que provocou uma progressiva retração nas margens de lucro do setor. Um dos aspectos da reestruturação da siderurgia mundial foi justamente a destruição da capacidade excedente, através do fechamento de algumas das unidades menos lucrativas, especialmente nos países europeus e nos Estados Unidos. Em 1984, o nível de utilização da capacidade voltou a subir, em relação ao de 1982, porém, com uma capacidade de produção em torno de $10 \%$ menor.

Tabela 6. Capacidade real e grau de utilização

do parque siderúrgico em regiões e países selecionados, 1974/84

\begin{tabular}{l|c|c|c|c|c|c|c|c|c|c|c|c|}
\hline Países/ & \multicolumn{1}{|c|}{1974} & \multicolumn{2}{|c|}{1976} & \multicolumn{2}{|c|}{1978} & \multicolumn{2}{|c|}{1980} & \multicolumn{2}{|c|}{1982} & 1984 \\
\cline { 2 - 12 } regiões & 1 & 2 & 1 & 2 & 1 & 2 & 1 & 2 & 1 & 2 & 1 & 2 \\
\hline EUA & 133 & 99 & 137 & 85 & 132 & 94 & 128 & 80 & 129 & 53 & 113 & 73 \\
CEE & 155 & 101 & 171 & 78 & 166 & 80 & 164 & 78 & 159 & 70 & 142 & 91 \\
Japão & 120 & 98 & 128 & 84 & 138 & 74 & 138 & 80 & 138 & 72 & 138 & 77 \\
Econ desenv. & 456 & 100 & 488 & 84 & 494 & 94 & 493 & 81 & 492 & 67 & 459 & 80 \\
Econ em des & 43 & 86 & 50 & 90 & 61 & 92 & 67 & 99 & 80 & 86 & 91 & 86 \\
Mundo capital. & 499 & 99 & 538 & 84 & 555 & 95 & 560 & 83 & 572 & 70 & 550 & 81 \\
\hline
\end{tabular}

Fonte: Extraido de Maciel (1988, p. 261).

Notas: Col 1. Corresponde à capacidade real (em 1000 toneladas). Col.2. Corresponde ao grau de utilização ou taxa operacional da capacidade real (em \%).

Os paises em desenvolvimento encontravam-se na fase de planejamento e de implantação dos projetos siderúrgicos com capacidade superior ao consumo interno. A maturação desses investimentos em novas plantas e/ou ampliação das existentes aumentou a capacidade de oferta no mercado mundial, ao mesmo tempo em que esses paises deixaram de ser uma opção de mercado para a siderurgia dos países desenvolvidos. A crise 
não atingiu da mesma forma a siderurgia dos paises em desenvolvimento, o que pode ser confirmado por dois aspectos: de um lado, a capacidade instalada evoluiu continuamente no período 1974/84 - um acréscimo correspondente a $116 \%$-; por outro lado, os níveis de utilização da capacidade instalada se conservaram elevados e superiores aos dos países desenvolvidos, durante quase todo o período - em 1982, ano mais crítico, o nível de ocupação alcançou $86 \%$, enquanto a média mundial foi de $70 \%$.

A ascensão dos produtores da periferia agravou o excesso significativo de capacidade instalada já presente em uma situação global de mercados deprimidos. Assim, as reduçōes que os produtores da CEE e dos Estados Unidos passaram a levar a cabo no segundo qüinquiênio dos anos de 1970 eram neutralizadas pela capacidade nova dos paises periféricos (Maciel, 1988, p. 67).

Apesar da retomada posterior do crescimento econômico, os efeitos da crise continuaram a se manifestar para o setor siderúrgico. $O$ aço, como discutido anteriormente, mostrou-se sempre bastante sensivel às variações cíclicas da atividade econômica. Durante as fases de descenso do ciclo, as firmas atrasam $o$ inicio dos seus projetos de investimento e, em geral, operam com capacidade ociosa acima do nível planejado; a construção civil, por sua vez, reduz o volume de obras (infra-estrutura, construção de edifícios e casas como também de novas plantas industriais); os consumidores protelam as compras de bens de consumo duráveis. Esses fatores fazem com que a taxa de consumo do aço seja muito reduzida durante as recessões. Não foi diferente durante a crise dos anos de 1970, embora até mais grave, já que o setor havia se preparado para a continuidade do crescimento industrial.

Assim, o decréscimo súbito do consumo mundial de aço foi explicado pela redução do nível da atividade econômica. Porém a crise dos anos de 1970 deu origem a uma série de questionamentos a respeito dos padrões técnicos adotados até então pelos mais diversos setores industriais, especialmente em relação às questões relativas ao uso dos insumos energéticos. Estes setores iniciaram um esforço para se readaptar às condições técnicas do novo ambiente competitivo, passando a adotar procedimentos que resultassem em redução dos niveis de consumo de energia e do desperdício de materiais. Dessa forma, a acentuada e contínua queda do consumo global de aço passou a ter outras explicações que estão ligadas, em grande medida, à própria reestruturação produtiva e tecnológica da indústria mundial.

A indústria siderúrgica enfrentou um duplo desafio diante dos resultados da crise dos anos de 1970: de um lado, teve que processar sua própria modernização frente ao aumento generalizado dos seus custos, à elevada capacidade ociosa e ao acirramento da concorrência internacional; 
de outro lado, foi obrigada a se preparar para as novas exigências do mercado consumidor, atentando mais para a qualidade e diversidade de seus produtos. Ou seja, sua reestruturação teria que modificar tanto os processos de produção quanto as linhas de produtos.

Nos países desenvolvidos iniciou-se um processo de redução da intensidade do uso do aço por unidade de produto (Steel Intensity) e do consumo per capita de aço. Essa redução se explica por alguns fatores. Em primeiro lugar, a maturidade dessas economias se exprime na existência de uma infra-estrutura econômica completa, cujo nível de investimentos é reduzido e menor do que o de países que passam por um processo de industrialização. Fases de rápida expansão industrial e de reconstrução, como no período pós-ll Guerra, requer insumos de aço para a construção de pontes, para as instalações portuárias, estações de energia, entre outras. Em segundo lugar, o alargamento da demanda por produtos eletrônicos e por serviços em relação à demanda por bens de consumo tradicionais e mais fortemente dependentes do aço na sua fabricação, tem contribuído para a redução relativa do aço no produto total. Em terceiro lugar, inovações tecnológicas em alguns setores industriais permitiram a substituição do aço por outros produtos, notadamente, alumínio, plástico e tubos de concreto, ou mesmo por aços mais leves e flexíveis, de tal forma que o consumo de aço nesses setores apresentou uma queda acentuada. Pode-se tomar como exemplo a produção de veículos em Detroit: em 1973, com uma produção de 14,5 milhões de veículos, foram consumidas 23 milhões de toneladas de aço; em 1985, 15,7 milhões de veículos foram produzidos com apenas 13 milhões de toneladas de aço - uma redução de $48 \%$ por unidade (Eichengreen, 1988, p. 300).

Os países em desenvolvimento, em geral, encontram-se na fase ascendente da curva da intensidade de aço, ou seja, tanto o consumo per capita quanto o consumo de aço em relação ao produto interno são crescentes nesse período, em decorrência dos processos internos de industrialização, do aumento da taxa de urbanização da população e da instalação da infra-estrutura econômica. Porém, não chegaram a se constituir em mercado para os paises desenvolvidos, pois também participaram do processo de ampliação da capacidade produtiva tornandose, muitos deles, exportadores e concorrentes no mercado internacional.

Um indicador revelador das possíveis tendências da demanda de aço é o seu consumo per capita. A Tabela 7 revela as disparidades desse indicador entre os países, bem como o comportamento durante os anos de 1980. O Japão, além de apresentar um dos maiores índices de consumo per capita de aço do mundo, teve um crescimento significativo no período $1982 / 91$, equivalente a $36 \%$. Os demais países industrializados, ao contrário, demonstraram uma estabilidade nesse índice e até uma queda a 
partir do final da década. Dentre os países em desenvolvimento, destacamse a Coréia do Sul e Taiwan, cujo consumo per capita mais que triplicou nesse período, enquanto os paises da América Latina situam-se na escala mais baixa, inclusive com quedas a partir de 1988, principalmente o caso brasileiro que não só apresenta o menor indice, como também teve uma queda equivalente a $23 \%$ no período considerado.

Tabela 7. Consumo aparente de aço bruto em regiões e países selecionados, 1982/1991 ( $\mathrm{Kg} / \mathrm{hab}$.)

\begin{tabular}{l|r|r|r|r}
\hline \multicolumn{1}{c|}{ Países/regiões } & \multicolumn{1}{c|}{1982} & \multicolumn{1}{c|}{1985} & \multicolumn{1}{c}{1988} & \multicolumn{1}{c}{1991} \\
\hline Países industrializados & 363,9 & 383,6 & 423,4 & 388,5 \\
Japão & 586,6 & 607,2 & 708,5 & 800,1 \\
Estados Unidos & 397,5 & 457,3 & 460,7 & 369,3 \\
CEE & 322,4 & 317,2 & 376,3 & 372,5 \\
Argentina & 96,3 & 64,3 & 88,1 & 68,8 \\
Brasil & 83,6 & 88,5 & 81,2 & 64,4 \\
México & 112,0 & 98,7 & 82,9 & 107,1 \\
Coréia do Sul & 194,0 & 277,1 & 377,2 & 605,3 \\
Taiwan & 274,9 & 328,0 & 584,6 & 916,5 \\
Europa oriental & 534,8 & 538,5 & 541,5 & 395,4 \\
Total mundial & 142,9 & 149,8 & 154,8 & 136,4 \\
\hline
\end{tabular}

Fonte: IISI (International Institute of Steel and Iron).

Diante da estagnação do mercado de aço e das reduzidas possibilidades de sua ampliação, as indústrias siderúrgicas tiveram de enfrentar $o$ acirramento da concorrência internacional. As práticas competitivas variaram de pais para pais - e aqui reside a grande diferença entre os Estados Unidos e o Japão. Enquanto o primeiro utilizou-se de políticas de cunho protecionista para enfrentar a queda de rentabilidade e a perda de competitividade em relação à siderurgia mundial, o segundo preocupou-se com a redução dos custos e com a incorporação de inovações de processos para aumentar a produtividade das plantas e com a diferenciação de produtos para ampliar seus mercados.

Embora a indústria siderúrgica tenha se caracterizado pela relativa ausência de inovações tecnológicas radicais, a não ser a introdução na aciaria de vasos conversores e o processo de lingotamento contínuo, não se pode desprezar importantes mudanças tecnológicas do tipo incremental ao longo dos últimos anos como formas de enfrentar, de um lado, a tendência declinante da rentabilidade em vista da capacidade ociosa e dos custos crescentes, e, de outro, o encolhimento dos mercados e as maiores exigências de qualidade e diversidade dos produtos por parte dos setores demandantes de aço. 
Essas inovações resultaram em melhoria dos indicadores de produtividade do setor siderúrgico: redução da coke-rate (consumo de coque por unidade de gusa produzido), redução substancial do consumo de energia por tonelada de aço bruto, bem como redução da mão-de-obra necessária por unidade de produto final. Esses incrementos de produtividade são acompanhados por melhorias da qualidade do produto, tornando-o mais resistente, mais flexível e mais adequado aos diferentes usos finais. Nesse sentido, a demanda de aço tende a ser cada vez menos padronizada e mais especializada, em conformidade com as necessidades e as características específicas dos setores usuários. Dessa forma, o setor siderúrgico, que teria sido considerado tipicamente um oligopólio homogêneo, vai alterando cada vez mais seu padrão de concorrência no mercado internacional, privilegiando a diferenciação do produto e o atendimento a encomendas específicas - a demanda torna-se o referencial básico da produção siderúrgica, ou seja, a tendência do mercado mundial de aço é deixar de ser um mercado genérico de commodities e assumir cada vez mais as características dos aços especiais. Assim, as usinas têm que se equipar de forma a flexibilizar os processos de fabricação e, considerando o relativo estancamento do mercado, se lançar no processo de diversificação de suas atividades, constituindo outra fase da concorrência mundial.

No bojo desse processo, surge espaço para o crescimento e a proliferação das chamadas miniusinas, que operam em pequena escala, baseadas na fusão de sucatas em fornos elétricos. Além das vantagens de custos reduzidos em relação às usinas integradas (preço estável e facilidades de aquisição das sucatas, baixo nível de utilização de energia, mão-de-obra mais barata), as miniusinas podem ser localizadas próximas dos mercados finais de seus produtos e promover um atendimento mais personalizado e específico da demanda. Nos Estados Unidos essas usinas ampliaram sua participação no mercado de aço de $3 \%$, em 1968, para 18\%, em 1983 (Kolko, 1988, p. 127).

Um bom indicador para avaliar o nível de atualização tecnológica do setor é o percentual de aço produzido em cada tipo de processo básico. A Tabela 8 mostra a difusão durante os anos de 1980 nos principais países e/ou regiões. Nota-se que o processo mais obsoleto (Siemens-Martin) teve uma redução de quase dez pontos percentuais durante a década, especialmente nos países da América Latina, cuja média de utilização desse processo ainda era bastante elevada em 1980, e nos Estados Unidos, com uma queda de $11,6 \%$, em 1980 , para $1,6 \%$, em 1991 . Os países do leste europeu, ao contrário, mantiveram um elevado percentual de uso desse processo - 46,1\%, em 1991 -, demonstrando o pouco dinamismo da siderurgia nessa região. E provável que as pequenas 
alterações durante a década se devam mais à desativação de capacidade produtiva (nas usinas menos eficientes), do que um esforço de renovação tecnológica. Nos países asiáticos esse processo já havia sido abolido desde os anos iniciais da década de 1980.

Tabela 8. Produção de aço bruto por processos

de refino em regiões e países selecionados,1980/1991 (\%)

\begin{tabular}{l|r|r|r|r|r|r|r|r|r}
\hline \multirow{2}{*}{\begin{tabular}{c} 
Regiōes/ \\
\multicolumn{1}{c|}{ Países }
\end{tabular}} & \multicolumn{3}{|c|}{1980} & \multicolumn{3}{c|}{1986} & \multicolumn{3}{c}{1991} \\
\cline { 2 - 8 } & BOF & EAF & SM & BOF & EAF & SM & BOF & EAF & SM \\
\hline Países industr. & $\ldots$ & $\ldots$ & $\ldots$ & 67,7 & 30,8 & 1,5 & 66,2 & 33,0 & 0,8 \\
Japão & 75,5 & 24,5 & 0,0 & 70,3 & 29,7 & 0,0 & 68,6 & 31,4 & 0,0 \\
EUA & 61,2 & 27,2 & 11,6 & 58,7 & 37,2 & 4,1 & 60,0 & 38,4 & 1,6 \\
CEE & 73,0 & 23,8 & 3,2 & 71,0 & 28,8 & 0,0 & 67,9 & 31,6 & 0,6 \\
Argentina & 26,1 & 53,7 & 20,2 & 44,0 & 45,4 & 10,5 & 46,7 & 53,3 & 0,0 \\
Brasil & 63,4 & 24,7 & 11,9 & 72,7 & 24,9 & 2,4 & 79,3 & 18,9 & 0,0 \\
México & 37,0 & 42,2 & 20,8 & 48,3 & 39,8 & 11,9 & 39,6 & 57,0 & 3,3 \\
Coréia do Sul & 69,2 & 29,7 & 1,2 & 65,5 & 34,5 & 0,0 & 70,9 & 29,1 & 0,0 \\
Taiwan & 32,9 & 67,1 & 0,0 & 65,7 & 34,3 & 0,0 & 53,1 & 45,0 & 0,0 \\
Europa Oriental & 29,6 & 12,0 & 58,4 & 35,6 & 15,1 & 49,4 & 39,2 & 14,7 & 46,1 \\
Total mundial & 55,0 & 22,0 & 23,0 & 55,9 & 25,9 & 18,2 & 58,5 & 27,7 & 13,8 \\
\hline
\end{tabular}

Fonte: IISI (International Institute of Steel and Iron)

Notas: BOF: Aciaria de vasos conversores; EAF: Forno a arco elétrico; SM: Processo Siemens-Martin e outros.

A utilização do forno a arco elétrico é um indicador da expansão das miniusinas na indústria siderúrgica. Durante a década de 1980, grande parte da expansão foi com base nesse processo, cujas características de flexibilidade no atendimento às demandas especificas dos consumidores $e$ as reduzidas escalas de produção foram extremamente favoráveis ao seu bom desempenho. A participação desse processo atingiu a média mundial de $27,7 \%$, em 1991 , sendo que nos Estados Unidos as miniusinas são responsáveis por $38,4 \%$.

A relativa estabilização da produção através da aciaria de vasos conversores, durante a década de 1980 , indica uma enorme cautela na decisão de investimentos com base nesse processo, tendo em vista o aumento da oferta que significa uma nova usina desse tipo no mercado mundial. Segundo estatisticas do IISI, atualmente $58 \%$ dos produtores de aço utilizam o processo BOF, $32 \%$ o forno a arco elétrico e $10 \%$ ainda usam o Siemens-Martin, especialmente nos países do leste europeu. $O$ ritmo de adoção do forno a arco elétrico sugere que, segundo a mesma fonte, no inicio do próximo século, esse processo alcançará paridade com o processo BOF. O maior problema a ser enfrentado é a disponibilidade de sucata, cuja demanda poderá superar em muito a oferta. 
A tendência verificada para os produtos planos, que representam cerca de $50 \%$ de todo o aço produzido, é aumentar a importância das chapas finas em relação às chapas grossas, dominantes até a crise dos anos de 1970. As inovações de produto são direcionadas para novas aplicações e para fazer frente aos materiais substitutos das chapas de aço.

Outro indicador de atualização tecnológica refere-se à introdução do lingotamento contínuo (Tabela 9). Mais uma vez observa-se a superioridade e a velocidade da adoção desse processo no Japão e nos países do leste asiático e o relativo atraso da siderurgia americana e da Europa Oriental. Enquanto os primeiros iniciam a década de 1990 próximos do índice de $100 \%$ de utilização desse processo, os Estados Unidos atingem $75 \%$ e a Europa Oriental tão-somente $18 \%$. O Brasil apresenta um dos menores índices de adoção do lingotamento contínuo dentre os países em desenvolvimento, atingindo $56 \%$, em 1991.

Tabela 9. Produção de aço bruto por lingotamento contínuo em regiões e países selecionados,1973/1991 (\%)

\begin{tabular}{l|r|r|r|r|r|r}
\hline \multicolumn{1}{c}{ REGIÓES/PAISES } & \multicolumn{1}{c}{1973} & \multicolumn{1}{c}{1975} & 1980 & 1985 & 1988 & 1991 \\
\hline Países industrializados & $\ldots$ & 18,4 & 39,4 & 68,8 & 80,1 & 87,1 \\
Japão & 20,7 & 31,1 & 59,5 & 91,1 & 93,1 & 94,4 \\
EUA & 6,8 & 9,1 & 20,3 & 44,4 & 61,3 & 75,1 \\
CEE & 9,4 & 16,5 & 39,1 & 69,7 & 84,2 & 90,3 \\
Argentina & 0,0 & 25,6 & 53,3 & 62,5 & 67,9 & 85,0 \\
Brasil & 3,2 & 5,7 & 33,4 & 43,7 & 49,0 & 56,0 \\
México & 12,1 & 13,2 & 29,3 & 51,0 & 55,9 & 62,0 \\
Coréia do Sul & 0,0 & 19,7 & 32,4 & 63,3 & 88,3 & 96,4 \\
Taiwan & 0,0 & 0,0 & 56,5 & 85,1 & 93,6 & 94,6 \\
Europa Oriental & $\ldots$ & 6,0 & 10,5 & 15,2 & 18,2 & 17,9 \\
Total mundial & 9,8 & 14,2 & 30,0 & 47,0 & 54,8 & 63,0 \\
\hline
\end{tabular}

Fonte IISI (International Institute of Steel and Iron)

Em relação às tecnologias de processo de produção de planos, podese delinear algumas características no pós-ll Guerra. Nos anos 1950 e 1960, quando a demanda estava aquecida, com a rápida expansão das economias industrializadas, a siderurgia buscou a ampliação das plantas, incorporando economias de escala significativas. Os produtos de aço, nesse período, eram destinados principalmente a grandes obras de construção civil e à fabricação de navios e de grandes máquinas e equipamentos, exigindo aço de alta resistência à fratura e excelente soldabilidade. Assim, o comportamento da demanda influenciou, em parte, as inovações tecnológicas introduzidas nesse período, com destaque para o alto-forno BOF, que praticamente triplicou a capacidade das usinas 
integradas, embora sem muitas possibilidades de variações rápidas no produto ofertado, caracterizando a baixa flexibilidade desse processo.

$\mathrm{Na}$ década de 1970, a siderurgia deparou-se com a crise energética e a elevação dos preços das matérias-primas básicas e uma forte retração da demanda. As inovações foram direcionadas para atender duas necessidades: redução de custos e oferta de produtos diversificados e de melhor qualidade, para concorrer com materiais alternativos e substitutos, como plásticos e alumínio. Esse periodo pode ser considerado como o do processo contínuo e da maior integração possivel entre as etapas das grandes usinas. A introdução e a rápida difusão do lingotamento contínuo foi a principal inovação dos anos de 1970; esse equipamento promoveu a articulação da aciaria com o laminador a quente, eliminando uma série de procedimentos e de equipamentos, além de incorporar uma elevada economia de energia. Nos laminadores a frio também foi realizada a integração entre os processos, com redução significativa do tempo de recozimento. As modificações da demanda dos produtos siderúrgicos foram no sentido de produtos mais leves, principalmente chapas finas, para atender a produção de eletrodomésticos e automóveis. Os pedidos provenientes das grandes construções e das grandes instalações industriais foram reduzidos e as exigências, a partir de então, são para produtos mais leves e poupadores de energia. Um outro segmento que se desenvolveu foram os produtos tubulares, com alta resistência à corrosão, para atender à exploração de novos recursos energéticos.

A década de 1980 consolidou as tendências que se manifestaram nos anos de 1970, aprofundando a diferenciação de produtos, a melhoria de qualidade e a produção em lotes menores. $O$ desenvolvimento das miniusinas se insere nesse contexto. Os esforços de P\&D se concentraram nas etapas finais - laminação, principalmente -, que são as etapas mais importantes para o desenvolvimento de novos produtos. "A produção de produtos de alta qualidade, para satisfazer as necessidades do mercado, tornou-se possivel com a introdução da tecnologia de laminação controlada e do Thermo-Mechanical Control Process (TMCP), através do emprego de laminadores avançados e tecnologia de resfriamento." (Tomiura et al., 1995, p.211).

A década de 1990 se caracteriza por duas fortes tendências que, no limite, são complementares: uma preocupação crescente com o meio ambiente e a busca de uma maior compactação das usinas, seguida de uma redução das escalas de produção. Do ponto de vista da demanda, a siderurgia vem adotando as estratégias de proximidade com o cliente, satisfazendo as necessidades especificas de qualidade, composição, tamanho, lotes reduzidos, observância dos prazos de entrega, enfim, características que são comuns a outros setores industriais, no período 
recente. Assim, o desenvolvimento da tecnologia de produtos é fortemente influenciado pela demanda.

\section{CONSIDERAÇÕES FINAIS}

Viu-se que, ao longo das décadas de 1970 e 1980, a siderurgia mundial, um dos setores industriais mais tradicionais e representativos da Segunda Revolução Industrial, sofreu um profundo processo de reestruturação, adaptando-se às mudanças introduzidas nos principais setores demandantes de aço, que se tornaram mais exigentes em termos dos custos e principalmente da qualidade do aço.

No primeiro momento, basicamente nos anos 1970 , a reestruturação concentrou-se na busca do aperfeiçoamento dos processos tecnológicos (tecnology push), visando a economias dos custos energéticos e à ampliação das escalas de produção, de forma a incorporar elevadas economias de escala, resultando em redução dos custos industriais. Ou seja, a origem das inovações esteve ligada às necessidades internas do setor, na busca de requisitos tecnológicos que solucionassem os problemas da elevação dos custos em função da crise energética. Nesse sentido, as mudanças mais importantes se traduziram na rápida difusão dos altosfornos a coque, com significativas economias de escala, conjugada à aciaria de vasos conversores (processo BOF).

Nesse processo houve um redesenho da siderurgia mundial, tendo o Japão despontado como a grande potência siderúrgica, onde aquelas inovações de processo foram rapidamente introduzidas. Por outro lado, a siderurgia norte-americana, líder mundial no setor até o início dos anos de 1970, que havia realizado pesados investimentos baseados na tecnologia anterior, experimentou um atraso tecnológico que provocou uma crise de graves conseqüências para as grandes usinas integradas. Esse atraso relativo abriu espaço para dois movimentos, ambos de confronto à sua lucratividade: as crescentes importações de produtos siderúrgicos especialmente provenientes do Japão - e a proliferação das miniusinas operando com custos bem inferiores e concorrendo para a queda dos preços do aço.

Ao mesmo tempo, muitos outros países, com destaque para os NICs latinos e asiáticos, desenvolveram internamente o setor siderúrgico, com uma base tecnológica atualizada, passando de importadores no mercado mundial a exportadores com grande poder de mercado, resultando não só na ampliação do comércio mundial de produtos siderúrgicos (um crescimento mais rápido que o da produção siderúrgica), como também na redefinição geográfica da produção de aço.

No segundo momento, a partir de meados dos anos de 1980, a 
prioridade da siderurgia passou a ser a adoção de inovações com novos produtos e com a melhoria da qualidade do aço. Essas inovações concentraram-se, sobretudo, nas etapas finais da produção (laminação) e foram conjugadas com importantes inovações de processo, necessárias para o aperfeiçoamento dos produtos como, por exemplo, o lingotamento contínuo. A prioridade da siderurgia, principalmente para os países que continuaram na liderança do setor, foi voltada para o desenvolvimento dos aços especiais, cujas características obedecem aos requisitos dos setores demandantes (demand pull): aços mais leves, mais finos, mais maleáveis, mais resistentes ao calor e à corrosão. Nesse sentido, o processo de busca por inovações teve como finalidade atender às necessidades dos setores demandantes, principalmente porque 0 aço começou a enfrentar sérias ameaças de substituição por outros materiais naquelas indústrias tradicionalmente consumidoras de aço, como a automobilistica, a de eletrodomésticos e a da construção civil.

O processo de aperfeiçoamento do produto foi tão intenso que os aços especiais tornaram-se concorrentes do próprio aço, adquirindo características de um novo material. Nesse sentido, a siderurgia criou condições para acompanhar as mudanças significativas que ocorreram na indústria mundial e ingressar definitivamente na chamada Terceira Revolução Industrial, senão como um setor líder mas, pelo menos, como um dos setores prioritários no fornecimento de materiais para os novos produtos. Tanto é assim que, normalmente, utilizam-se os índices de produção de aços especiais de um determinado país para caracterizar o seu nivel de atualização tecnológica.

\section{BIBLIOGRAFIA}

ASTIER, J. E. Tendências tecnológicas na produção de aço Metalurgia e Materiais. Vol. 51, n. 439, p. 206-7, mar. 1995.

BARNETT, D. F e CRANDALL, R. W. Up from the ashes. The rise of the steel minimill in the United States. Washington, D. C.: The Brookings Institution, 1986

BNDES Siderurgia brasileira: questões e perspectivas para a próxima década. Rio de Janeiro: Departamento de Estudos - DEEST, 1987.

BORRUS, $M$. The politics of competitive erosion in the U $S$ steel industry. In: ZYSMAN, J.e TYSON, L. (ed.). American industry in international competition. New York Cornell University Press, 1983, p. 60-105

COUTINHO, L. G. Percalços e problemas da economia mundial capitalista In. BELLUZZO, L. G. M. e COUTINHO, C. Desenvolvimento capitalista no Brasil: ensaios sobre a crise. São Paulo: Brasiliense, 1982

CRANDALL, R. W. The US. steel industry in recurrent crisis: policy options in a competitive world. Washington, D.C.: The Brookings Institution, 1981

EICHENGREEN, B. et al. Intemational competition in the products of U.S basic industries. In: FELDSTEIN, M. (ed.). The United States in the world economy. Chicago: The University of Chicago Press, p. 279-366, 1988 
HOGAN, W. T. Minimills and integrated steel plants. In SCHOLES, P.H. (ed.). Steel Technology International - 1994/95. London: Sterling Publishing Group PLC, p 27-30, 1994

IISI - INTERNATIONAL INSTITUTE OF STEEL AND IRON. Steel Statistical Yearbook Bruxelas (vários anos).

JONES, K. Politics vs economics in world steel trade. London: Allen \& Unwin, 1986.

KOLKO, J Restructuring the world economy. New York: Pantheon Books, 1988.

LANDES, D.S (1969) Prometeu desacorrentado transformação tecnológica e desenvolvimento industrial na Europa Ocidental, desde 1750 até a nossa época. Rio de Janeiro: Nova Fronteira, 1994.

MACIEL, C. S. As mudanças estruturais no mercado mundial de aço e os desafios a competitividade internacional da indústria siderürgica brasileira Campinas, IE/UNICAMP, Dissertação de mestrado 1988

OBERENDER, P. e RUTER, G. The steel industry: a crisis of adaptation. In: JONG, H.W. (ed.). The structure of european industry. London: Kluwer Academic Publishers, p. 81104, 1988

PAULA, G M. Avaliação tecnológica da siderurgia brasileira Rio de Janeiro: IEJUFRJ, Dissertaçăo de mestrado, 1992.

Competitividade da indústria siderúrgica. Relatório de pesquisa do projeto Estudo da competitividade da indústria brasileira. Campinas, IE/UNICAMP-IEI/UFRJ-FDCFUNCEX, 1993.

SZEKELY, J. Some perspectives on steel industry technology In: SCHOLES, P. H. (ed). Steel technology international - 1994/95. London. Sterling Publishing Group PLC, p. 2126, 1994 .

TOMIURA, $A$ et al Progresso e perspectivas futuras de produtos planos e tecnologias. Metalurgia e Materiais - ABM, v. 51, n. 439, p 210-215, mar 1995

WIESINGER, $H$ et. al A usina siderúrgica do futuro. Metalurgia e materiais - $A B M, v, 51, n$ 439, p 206-7, mar 1995 